\section{溶鉄および溶融スラグ中の成分のトランス ポート係数とカップリング現象}

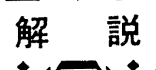

後 藤 和 弘*

\title{
Transport Coefficients of Components in Molten Iron and Slag and Coupling Phenomena
}

\author{
Kazuhiro Sylvester GoTo
}

\section{1. 不可逆過程の熱力学とトランスポート係数の 定義}

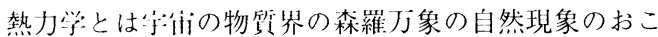
る叮能性を亦すひとつの学閣体系である。したがつて熱

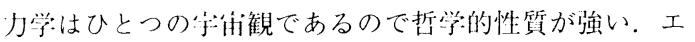
ネルギーとかエントロピーというような目に見えない抽 象的な概念を用いた沉の法則のみで自然現象すべてを とりあつかう。抽禹的誉開に约いといわれている我々日 本人にとつてはこの学閆を深く理解するには相当の努力 を必要とする。

熱力学:は第 1 法則, 第 2 法剘, 第 3 法則の三つの法則 から成り立つて, いろいろな自然現象が最終平衡状態に 到達するとどのような状俧になるかという予測をするこ とができる。このように衡状態をもつぱら取り扱う学 問体系であるが，その第2 法則，すなわちエントロピー 増大の法則から派生して, もつぱら不叮逆過程の現象を とりあつかう分野がありこれを不叮逆過程の熱力学と 称する。

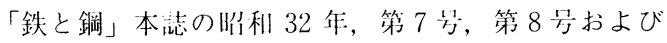
第 10 等の 3 回にわたつて当時東京大学助教授であつた 松下涬雄先生が講義」“非叮逆現象の取扱い力”之題 して，我が国の鉄鐦兴界にはじめてこの学問を紹介して

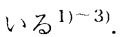

この 3 [凹の講義は不川逝過程の熱力了学:の㓣立期の第一 人者であつたベルギーの $I$. PRIGOGINE 教授の許叮を得て 闹氏の本 ${ }^{4)}$ を松下克脽筧生が具体的な例を用いながら 平易に解説しているのでこの 3 回の講義につけ加えるも のは何も無い.

筆者は昭利 37 年から 41 年にわたつて松下研究坴で この学:問分野を学:び, 後にこの不川逆過程の熱力学に関
係する実験をいくつか行つてきたので以下に紹介する．

不可逆過程の熱力学で興味深いことは, 古典熱力学の 第 2 法則を個々の単独の現象にあてはめてみると生起し ないような現象でも同時に抗こすとカップリング効果で 全体のエントロピー生成が正であるかぎりそれらの現象 は進行するということである。

不叮逆過程の熱力学でいう単位時間, 単位体積あたり のエントロピー生成速度を計算するにはまず線形の方程 式の紹介からはじめなければならない。本当は松下幸雄

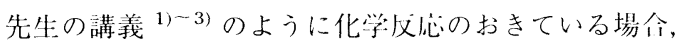
拡散のおきている場命，熱伝導の挹きている場令のそれ ぞれのエントロピー生成速度はこうなるという説明をつ み重ねてゆきこれらを統一的に考えなおすとエントロ ピー生成速度はどのようになるかという議論の展開にし なければならないが，本稿では紙面の都今で線形の方程 式の紹介からはじぬる.

今仮りに鉄鋼製鍊スラグに関連の深い $\mathrm{CaO}-\mathrm{SiO}_{2} 2$ 元系融体が温度勾配の存在している条件下で拡散してい る場今を考えてみよう。

成分は簡便のため $\mathrm{Ca}^{2+}, \mathrm{Si}^{4+}, \mathrm{O}^{2-}$ と示し，それ らを $1,2,3$ の数字:で表現する。また伀熱現象は 4 とい う数字で表現する。ある内部夾標に対する $\mathrm{Ca}^{2+}, \mathrm{Si}^{4+}$, $\mathrm{O}^{2-}$ の拡散の流束を $j_{1}, j_{2}, j_{3}$ で示し熱伝導速度を $j_{4}$ で示すと次のように示さ机る。

$$
\begin{aligned}
& j_{1}=L_{11} X_{1}+L_{12} X_{2}+L_{13} X_{3}+L_{14} X_{4} \cdots \cdots(1) \\
& j_{2}=L_{21} X_{1}+L_{22} X_{2}+L_{23} X_{3}+L_{24} X_{4} \cdots \cdots(2) \\
& j_{3}=L_{31} X_{1}+L_{32} X_{2}+L_{33} X_{3}+L_{34} X_{4} \cdots \cdots(3) \\
& j_{4}=L_{41} X_{1}+L_{42} X_{2}+L_{43} X_{3}+L_{44} X_{4} \cdots \cdots(4)
\end{aligned}
$$

ここで $L_{i k}$ はトランスポート係数とよばれ， $X_{i}$ は $\mathrm{Ca}^{2+}, \mathrm{Si}^{4+}, \mathrm{O}^{2-}$ に作用している拡散の駆動力であり， $X_{4}$ は熱伝導の駆動力であり次のように示される.

昭和 61 年 7 月 25 月受付 (Received July 25, 1986) (依頼解説)

*東宗1.業大学: 部教授 I. 博 Ph. D. (Faculty of Engineering, Tokyo Institute of Technology, 2-12-1 Ookayama Meguro-ku, Tokyo 152)

Key words : molten iron ; molten slag ; component ; transport coefficient ; couppling ; thermodynamics ; irreversible ; kinetics. 


$$
\begin{aligned}
& X_{1}=-\frac{d}{d x}\left(\mu_{\mathrm{Ca}^{2+}}+2 F \psi\right) \\
& X_{2}=-\frac{d}{d x}\left(\mu_{\mathrm{Si}^{+}+}+4 F \psi\right) \\
& X_{3}=-\frac{d}{d x}\left(\mu_{0^{2-}}-2 F \psi\right) \\
& X_{4}=-\frac{d \ln T}{d x} \ldots \ldots \ldots \ldots \ldots
\end{aligned}
$$

ここで $x$ は距離, $\mu_{i}$ は化学ポテンシャル， $F$ はファラ デー常数, $\psi$ は電位, $T$ は絶対温度である.

（1）～(4) 式は線形の式とよばれトランスポート係 数の定義の式である。この線形の式は熱力学の第 1 , 第 2 , 第 3 法則がすべて実験結果にもとづいた経験的法則 と同じように実験結果にもとづいた経験則である.

(1)一(4) 式の $L_{11}, L_{22}, L_{33}, L_{44}$ は Diagonal terms とよばれ常に正の値をとる。またそれ以外の $L_{i k}$ $(i \neq k)$ は Cross terms とよばれ正や負の值をとりカッ プリング現象の程度を定量的に示している。

したがって（1）～(4) 式で定義されるトランスポー 卜係数を定量的に知ることはいろいろな種類のカップリ ング現象の㧍きる程度を知る上でたいへん重要になつて くる。また $L_{i k}$ を求める目的はカップリング現象のお きる速度を知ることに役立つばかりでなく, 搪散倸数, 電気伝導度, イオンの輸率, 熱起電力, 熱拡散のソレー 係数などいろいろの物理的性質の相互関係を定量的に明 らかにする上でもたいへん便利である。

\section{2. カップリング現象とエントロピー生成速度}

二つの現象がカップリングするためには二つのミクロ 機構が直接的関倸を有していなけ机ばならない.

Fig. 1 は上から (a) カチオン同志の拡散のカップ リング，(b) 伝熱と酸化物 MO 中不純物 Xの拡散のカッ プリング，（c）伝熱と金属酸化物 MOのチャージ分離 (熱起電力) とのカップリングの微細機構を概念的に示 した罒である。

(a) においては $\mathrm{CaO}-\mathrm{SiO}_{2}-\mathrm{Al}_{2} \mathrm{O}_{3}$ 液体中で $\mathrm{CaO}$ と $\mathrm{SiO}_{2}$ のみに濃度公配がある場令, $\mathrm{Al}_{2} \mathrm{O}_{3}$ は均一濃度で 搪散の駆動力は $\mathrm{Al}^{3+}$ に作用していないにもかかわら ず， $\mathrm{Ca}^{2+}$ のジャンプにより電気的中性条件よりすこし $\left\ulcorner\mathrm{Al}^{3+}\right.$ も」左に移動する川能性があることを示してい る.

(b) の $\mathrm{M}^{2+}$ イオンと $\mathrm{O}^{2-}$ イオンの閪のギザギザは 熱振動の振幅を示している.すなわち振幅の大きい方方 から有方へ伝熱が㧍きていて，振幅勾配のためMO中 にある不純物Xが左有どちらかに搪散ジャンプする叮能 性を示している.

（c）はイオン性結合をしている金属酸化物 MO の熱 起電力の生ずる原因を概念的に説明した汹であり， $\mathrm{M}^{2+}$ と $\mathrm{O}^{2-}$ の平均存在位置が温度勾配のため一定温度下で の存在位置から少し移動したためと説明している. (a)

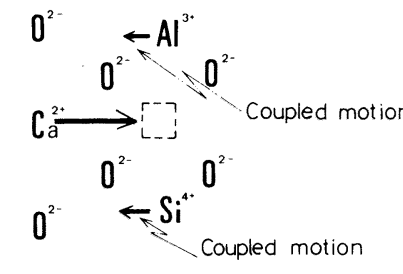

(b)

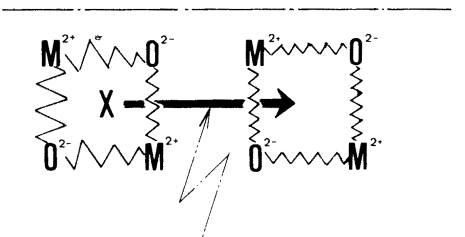

$$
\mathrm{M}^{2+} \mathrm{O}_{\text {Coupled motion of }}^{\mathrm{M}^{2-}} \mathrm{X}^{\mathrm{O}^{2}}
$$

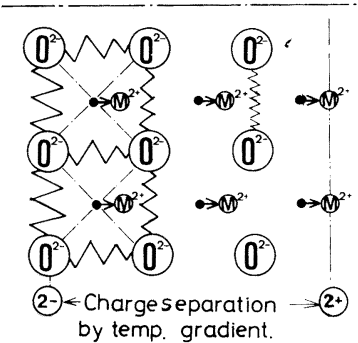
(a) Coupling among ternary diffusion jumps (b) Coupling between
heat conduction and diffusion of $X$ disolved in MO Coupling
between heat conduction and charge separation in an ionic crystal
MO

Fig. 1. Three conceptional pictures to show three kinds of coupling phenomena.

Fig. 1 は拡散, 伝熱, 熱起電力などのカップリング を説明したが，化学仪忍速度そのものが律速になつてい る二つの化学反伈がカップリングする場们を考えてみよ う.

$$
\begin{aligned}
& A(\mathrm{~g})+B(\mathrm{~g})=A B(\mathrm{~g}) \\
& B(\mathrm{~g})+C(\mathrm{~g})=B C(\mathrm{~g})
\end{aligned}
$$

(9) と（10) がカップリングしているというために は (9）の为匛エントロピー生成速度 $\left(d S_{1} / d t\right)$ はフ ラス，(10)のそれ $\left(d S_{2} / d t\right)$ はマイナス，しかしその 利がプラスであるときはじめでつの化学沌心はカップ リングしていると市う。すな⿰七

$$
\frac{d S_{1}}{d t}+\frac{d S_{2}}{d t}>0, \text { ただし } \begin{gathered}
d S_{2} \\
d t
\end{gathered}<0 \cdots \cdots \cdots
$$

こんなことが生起するためには中䦌活性体が例えば $A B_{2} C$ のように $A B C$ の 3 成分を含有している必要があ る.

$$
\begin{aligned}
& \text { すなわち } \\
& \quad A+2 B+C \longrightarrow A B_{2} C^{+} \longrightarrow A B+B C \quad \cdots \text { (12) }
\end{aligned}
$$$$
\text { このようにカップリング現象が临じる埸介には必ずそ }
$$ 
の微練機構において似らかの值接的原因がなければなら ない.さて, エントロピー生成速度 $\left(\mathrm{cal} / \mathrm{s} \cdot \mathrm{cm}^{3}\right)$ は, 次のようにホされる4).

$$
d S=\sum_{i} X_{i} j_{i}
$$

例えば一つの流束のみがある場命には

$$
\begin{aligned}
& j_{1}=L_{11} X_{1}+L_{12} X_{2} \\
& j_{2}=L_{21} X_{1}+L_{22} X_{2}
\end{aligned}
$$

この 2 式を（13）式に代人すると

$$
\frac{d S}{d t}=L_{11} X_{1}{ }^{2}+\left(L_{12}+L_{21}\right) X_{1} X_{2}+L_{22} X_{2}{ }^{2} \cdots \text { (16) }
$$

このエントロピー生成速度が $X_{1}$ と $X_{2}$ のどんな值に 対しても正であるためには初歩的な代数学より，

$L_{11}>0, L_{22}>0$ かつ $\left(L_{12}+L_{21}\right)^{2}<4 L_{11} L_{22} \cdots$ (17)

この関倸は $d S / d t$ が正でなければならないという熱 力学第 2 法則から得られたことになる。またオンセー ガーの相父起理から

$$
L_{12}=L_{21}
$$

この们名な分埋の证明は文献 4)にある.

さてこのように $L_{i k}$ の値を走量的に知ることができる と（16）式にしたがつていろいろなカップリング現象が おきているその場所の $1 \mathrm{~s}, 1 \mathrm{~cm}^{3}$ あたりのエントロピー 生成速度が们力ロリー/度であるかが是量的に求められ る. $L_{i k}$ を分量的に知ることができればこのような学問 的問題に是量的な解答を与えることができる.

松下幸雄先生が約 30 年前に「鉄と鋼」で 3 回にわた つて講義された不仃逆過程の熟力学を鉄鋼製錬丁程に忘 用するには，占㭁か堭炉内で作起しているであろう諸現

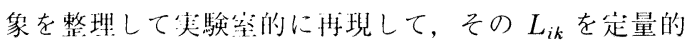
に測定しなければならない。

\section{3. トランスポート係数 $L_{i k}$ と実測可能な諸 物性値との関係}

さて $L_{i k}$ を浴鉄や高必スラグ，転炉スラグについて 実測にもとづいて求めようとする場合に（1）－（4）式 をもう少し整理して $L_{i k}$ と実測叮能な諸物性值との関 係式を求めて㧍かなけ机ばならない。例えば（1）式に (5)（）式を代人して非等温の条件で $\mathrm{CaO}-\mathrm{SiO}_{2}$ 融 体中を $\mathrm{Ca}^{2+}$ が搪散している場命の拡散フラック石を 書いてみよう.

$$
\begin{gathered}
j_{\mathrm{Ca}^{2+}}=-L_{11} \frac{d}{d x}\left(\mu_{\mathrm{Ca}^{2+}}+2 F \psi\right)-L_{12} \frac{d}{d x} . \\
\left(\mu_{\mathrm{Si}^{4+}}+4 F \psi\right)-L_{13} \frac{d}{d x}\left(\mu_{0^{2-}}-2 F \psi\right) \\
-L_{14} \frac{d}{d x}(\ln T) \ldots \ldots \ldots \ldots \ldots \ldots \ldots \ldots \ldots \ldots \ldots \ldots \ldots \ldots \ldots \ldots \ldots
\end{gathered}
$$

この (19) 式の不便な点は原理的に実測不叮能な $\mathrm{Ca}^{2+}, \mathrm{Si}^{4+}$ や $\mathrm{O}^{2-}$ のようなイオンの化学ポテンシャ ルを含んでいることである.また電位，中は実測可能で あるがこのような填が入つていると（19）は不便である.
したがつて（19）の中のイオンの化学ポテンシャルを $\mathrm{CaO}$ や $\mathrm{SiO}_{2}$ のような化令物の活量におきかえ，また 電位も成分の活量に㧍きかえて抢くと他の実測叮能な諸 物性值から $L_{i k}$ が比較的簡単に計算で求められる.

この $L_{i k}$ と諸物性值の関倸を示す理論的関係式の蜱 出方法は文献 5 ) と6) に詳述してあるので以下に得ら れた関係式のみを示す。

今仮りに一定温度で $\mathrm{CaO}-\mathrm{SiO}_{2}-\mathrm{Al}_{2} \mathrm{O}_{3} 3$ 元系液体又 ラグ中に濃度勾配があり相互に拡散している場令の $\mathrm{CaO}$ と $\mathrm{SiO}_{2}$ の搪散の外部坐標に対するフラックスは それぞれ次のごとく示される。

$$
\begin{aligned}
& J_{10}=-\tilde{D}_{10-10}^{30} \frac{d C_{10}}{d x}-\tilde{D}_{10-20}^{30} \frac{d C_{20}}{d x} \\
& J_{20}=-\tilde{D}_{20-10}^{30} \frac{d C_{10}}{d x}-\tilde{D}_{20-20}^{30} \frac{d C_{20}}{d x}
\end{aligned}
$$

ここで $\tilde{D}_{i k}$ は相石拡散係数マトリックスとよばれる もので (20) 式と（21）式は 3 元拡散のFICKの第 1 法 則であり，したがつて実験式である。また $\tilde{D}_{i k}^{30}$ と上ッ キの位㯰に 30 がついているのは $J_{30}=-\left(J_{10}+J_{20}\right)$ と いう近似を用いていることを意味している。もし拡散に よつて体積変化の生じない場合はこの近似は正しくな り，かつ（20）式，(21）式は厳密に外部座標に対する 拡散フラックスとなる.

(20) 式と (21) 式で定義される $\tilde{D}_{i k}$ は拡散対の一定 時間拡散実験の後の濃度分布より求めることができ $ろ^{7) 8)}$.

この実測可能な $\tilde{D}_{i k}$ と $L_{i k}$ の関係は少し長い式にな るが $\tilde{D}_{10-10}^{30}$ を例にとつて示すと以下のようになる.

$$
\begin{aligned}
& \tilde{D}_{10-10}^{30}=\frac{R T}{C}\left[\frac{C_{20}+C_{30}}{C_{10}} T_{11}-T_{21}-T_{31}\right. \\
& \left.-\frac{C_{10}}{C_{30}}\left(\frac{C_{20}+C_{30}}{C_{10}} T_{13}-T_{23}-T_{33}\right)\right] \Gamma_{10} \cdots
\end{aligned}
$$

ここで $C$ は $C_{10}+C_{20}+C_{30}$ であり $\Gamma_{10}$ は成分 10 の 活量によつてきまる熱力学的ファクターである。 (22) 式 の中の $T_{i k}$ は $L_{i k}$ を単純にかけたりたしたりしたもの で $L_{i k}$ がわかれば簡単にわかる項である ${ }^{5) 6)}$.

(22) 式と同じような関係式が $\tilde{D}_{10-20}^{30}, \tilde{D}_{20-10}^{30}, \tilde{D}_{20-20}^{30}$ についても得られるので（20）式，(21）式で定義され た $\widetilde{D}_{i k}$ と $L_{i k}$ の厳密な関係式が四つ得られる.

次にイオン電導を示す多元系スラグの電導度 $\sigma$ と $L_{i k}$ の関係は次のように示すことができる ${ }^{6)}$.

$$
\sigma=F^{2} \sum_{i} \sum_{k} z_{i} z_{k} L_{i k}
$$

ここで $F$ は前も出てきたがファラデー常数である.

イオンのトレーサー拡散係数 $D_{i}^{t r}$ と $L_{i k}$ の関係は LAITY $^{9)}$ が次のように書いている.

$$
D_{i}^{t r}=\frac{L_{i i} R T}{C_{i 0}}
$$

$r$ 成分を基準にした $i$ 成分のヒットルフの輸率は次の ようになる。 


$$
{ }_{H} t_{i}^{r}=\frac{Z_{i}}{S} \sum_{k} z_{k}\left(L_{i k}-L_{r k} \frac{C_{i}}{C_{r}}\right)
$$

ここで $S$ は $L_{i k}$ の関数である ${ }^{6)}$.

はじめの方に出てきた（4）式の $L_{44}$ と熱伝尊度 $\lambda$ の関係は次のごとくなる。

$$
L_{44}=T \lambda
$$

ここで $T$ は絶対温度である。

次に熱昖散のソレー係数 $s$ と $L_{i k}$ の関係を示す。 今 伋りに $\mathrm{CaO}-\mathrm{SiO}_{2}$ の均一な液体にある一定の温度勾配 をつけ非常に長時開そのままの温度勾配に保持する。す ると $\mathrm{CaO}$ と $\mathrm{SiO}_{2}$ は熱拡散を招こし最終的には一定の 濃度分布になる。ソレ一係数 $s$ はこの最終濃度分布よ り次のごとく定義される.

$$
s \equiv\left(\frac{d \ln N_{\text {cao }}}{d x}\right) /\left(\frac{d T}{d x}\right)=\frac{d \ln N_{\text {cao }}}{d T} \cdots \text { (27) }
$$

ここで $N_{\mathrm{Ca}()}$ は $\mathrm{CaO}$ のモル分率である.

$\mathrm{CaO}$ の希薄溶液ではこの $s$ と $L_{i k}$ は次の関係にある。

$$
s=\left(\frac{1}{R T^{2}}\right) \times\left(\frac{T_{13}}{T_{11}^{-1}}\right)
$$

ここで $T_{i k}$ は（22）式の中の $T_{i k}$ と闬じ性質のもので ある。

次に以下のような電池の熱起電力を考えてみよう.

$T_{1}, P_{0_{2}}^{\prime}, \mathrm{Pt} \mid \mathrm{CaO}-\mathrm{SiO}_{2}$ (均一濃度液体) $\mid \mathrm{Pt}, P_{\mathrm{O}_{2}}^{\prime \prime}, T_{2}$

この電池の電解質は $\mathrm{Ca}^{2+}$ イオン電尊体の液体 $\mathrm{CaO}-\mathrm{SiO}_{2}$ であり左有の電極の温度と酸素分历:が異なつ ている.この場令の実測される起電力は次のようにな $\succsim^{6)}$.

$$
\begin{aligned}
& E=\frac{1}{4 F}\left[\mu_{0_{2}}\left(T_{2}, P_{0_{2}}^{\prime \prime}\right)-\mu_{0_{2}}\left(T_{1}, P_{0_{2}}^{\prime}\right)\right] \\
& -\frac{1}{2 F}\left[\mu_{\text {cao }}\left(T_{2}\right)-\mu_{\text {cao }}\left(T_{1}\right)\right] \\
& +\frac{1}{2 F} \int_{\mathrm{T}_{1}}^{T_{2}}\left(S_{\mathrm{Ca}^{2}+}+\frac{Q_{\mathrm{Ca}^{2+}}}{T}\right) d T \\
& -\frac{1}{F} \int_{T_{1}}^{T_{2}}\left(S_{e}^{\mathrm{Pt}}+\frac{Q_{e}^{\mathrm{Pt}}}{T}\right) d T
\end{aligned}
$$

この式の右辺第 1 項と第 2 項は正味の電池义心放す る $\Delta G$ によつて生じる反伈の起電片であり，第 3 項の 積分项は液体 $\mathrm{CaO}-\mathrm{SiO}_{2}$ の絶対熱電能であり, 最後の 積分填は固体白全の絶対熱暼能である。式中の $S_{\mathrm{Ca}^{2+}}$ は $\mathrm{CaO}-\mathrm{SiO}_{2}$ 液体中の $\mathrm{Ca}^{2+}$ イオンの部分モルエントロ ピーであり， $Q_{\mathrm{Ca}^{2}}$ は $\mathrm{Ca}^{2+}$ イオンの $\mathrm{CaO}-\mathrm{SiO}_{2}$ 中の トランスファー熱である。また $S_{e}^{\mathrm{Pt}}$ は葫体白金中の電 子の部分モルエントロピーであり， $Q_{e}^{\mathrm{Pt}}$ は白金中のエレ クトロンのトランスファー熱である.

(29) 式でホす起電功と $L_{i k}$ との直接的な関係式は得 られないが， $L_{i k}$ は $Q_{i}$ と比較的簡単な関係式が得られ る6)ので，Eと $L_{i k}$ は開接的には関係づけることがで きる。

なお電池に用いた $\mathrm{CaO}-\mathrm{SiO}_{2}$ 液体電解質ははじめは 均‥組成になつているが， $T_{1}$ と $T_{2}$ は簧なるのでいず
れは熱拡散を生じ濃度公配を生じるので（29）式の起電 力も時間と共に不辺第 2 项が省化するが, $\mathrm{CaO}$ と $\mathrm{SiO}_{2}$ の熱拡散はかなり拈そいと考えられるので初期の起電力 を測定すればよい。

以上のように(1)〜（４）式で足我されたトランスポー 卜係数 $L_{i k}$ と実測问能ないろい万な物性値との関倸式 が得られたので $L_{i k}$ を種々の多元系について走星的に

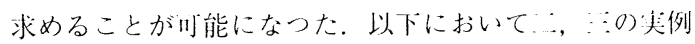
を示すが，その前に「トランスポート係数を知るとどん な便利なことがあるか？」をもう一度考えてみよう，上 記の（22）式より（29）式にわたつて $L_{i k}$ と楛物性值

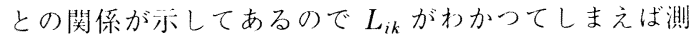
定されていない物性值を推定できることになる。また䦌 接的にではあるが， $L_{i k}$ をと扩して物理们意味の買なる 二つの物性値の閆の相ケの関倸が得られるので $L_{i k}$ 己 えわかつて执机は、一少を他版ら推往できる。

例えば文献 10)に示してあるように， $\mathrm{Ca}^{2+}$ が㲠父を はこぶ液体 $\mathrm{CaO}-\mathrm{SiO}_{2}-\mathrm{Al}_{2} \mathrm{O}_{3}$ スラグ巾の Nl:RNiTEINSTHIN 式は次のようになる.

$$
\begin{aligned}
& \sigma=F^{2}\left(\frac{4 C_{1}}{R T} D_{\mathrm{Ca}^{2+}}^{l r}+8 L_{12}+6 L_{13}-4 L_{10}\right) \cdots(30) \\
& \text { ここで } \sigma \text { はスラグの熋具度, } C_{1} \text { は } \mathrm{Ca}^{2+} \text { の濃度, }
\end{aligned}
$$
$D_{\mathrm{Ca}^{2}+}^{t r}$ は $\mathrm{Ca}^{2+}$ イオンのトレーサー抬散係数, $L_{i k}$ は卜 ランスポート係数で1,2,3,0 はそ机ぞれ $\mathrm{Ca}^{2+}, \mathrm{Si}^{4+}$, $\mathrm{Al}^{3+}, \mathrm{O}^{2-}$ を意味する。

\section{4. 溶鉄, 溶融スラグ中の成分のトランスポート 係数の推定}

低融点全金の熱搪散を测定した研究はいくつかある が11，溶鉄中の熱搪散を研究したのは䰻部南基先牛と 坟毛弘先生の 1973 年の研究 ${ }^{12)}$, 筫考らによる 1982 年 の研究しかない13).

溶鉄にもうひとつの成分 $X$ が人つている满令の $X$ の 拡散のフラックスと伝熱のフラックスはそ扎ぞれ次のよ うにかける。

$$
\begin{aligned}
& j_{1}=-L_{11} d \mu_{X}-L_{12} d \operatorname{dn} T \\
& d x \\
& j_{2}=-L_{21} d \mu_{x}-L_{22} d \ln T \\
& d x
\end{aligned}
$$

ここで $\mu_{X}$ は $X$ 成分の化受ホポテンシャルである.

この式の $L_{11}$ は (24) 式により条成分のトレーサー 搪散係数の文献值より湖算できる。また， $L_{22}$ も(26)

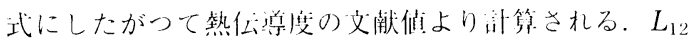
$\left(=L_{21}\right)$ は $(28)$ 式より次のように䞄される.

$$
s=\frac{1}{R T^{2}} \times \frac{L_{12}}{L_{11}}=d \ln N_{i}
$$

な抢このソレー係数は本によつてはに:の（33）式にマ

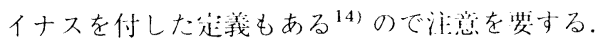

（31）式と（32）式で这義される4湖の $L_{i k}$ を水める 


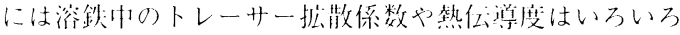

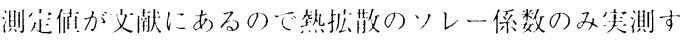
ればよい。

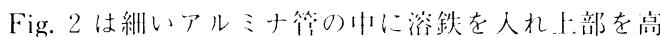

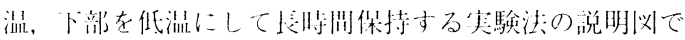
ある。

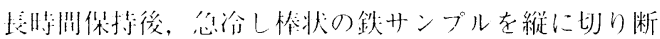
而在よくみがきX線マイクロアナライザーで成分の濃度

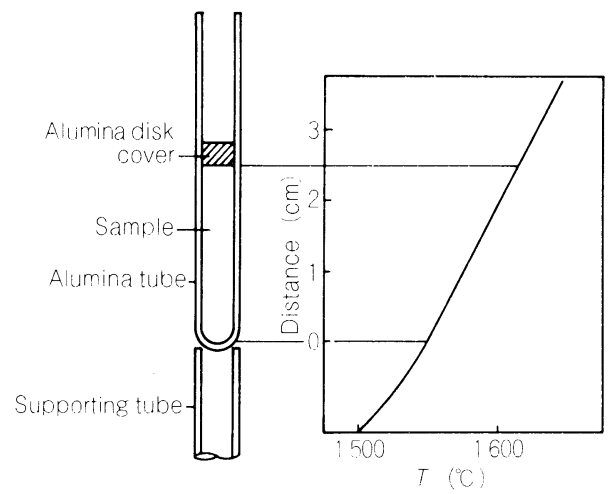

Fig. 2. Schematic picture of a long Alumina crucible with a fixed temperature gradient.

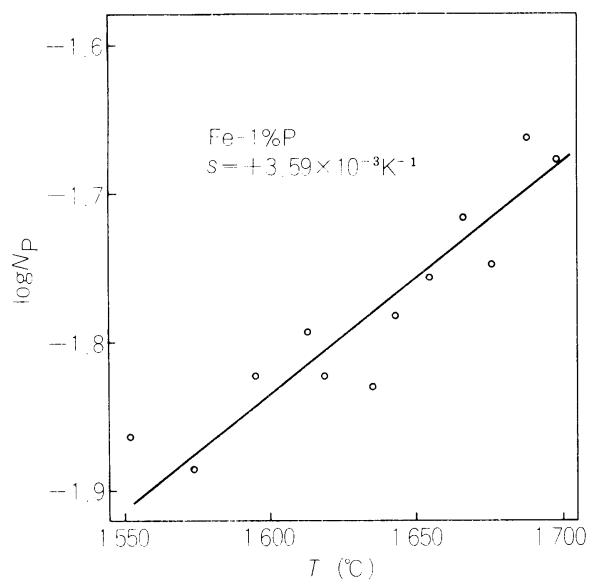

Fig. 3. A steady state distribution of phosphorus in liquid iron after thermodiffusion. The soret coefficient is $3.59 \times$ $10^{-3} / \mathrm{K}$.
分布を分析する。俱験方法の詳細は文献 13) にある。

Fig. 3 は…例として $\mathrm{Fe}^{-1} \mathrm{wt} \% \mathrm{P}$ 令金の上开を

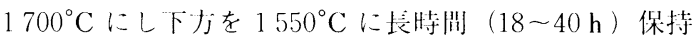
した後のPの分析結果であり，サンプルの長さは約 30 $\mathrm{mm}$ である。

この炏より，Pは1 wt％贪有の場仝は高温側に拡散 することがわかり，ソレー係数は $+3.59 \times 10^{-3} / \mathrm{K}$ と なつた。

间様の験結果を $12 \mathrm{wt} \% \mathrm{Si}, 11 \% \mathrm{P}, 10 \% \mathrm{P}, 5 \% \mathrm{Si}$,

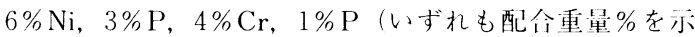
す)の測定結果をFig. 4 に亦す. 㲸中点線の Si と P についての測起結果は鰐部吉基，坂尾弘両先生の先駆的 研究結果である。

Table 1 はFig. 4 のイ倞, 後藤の測定結果より計算 した $L_{i k}$ の值を亦している。この表の温度は半均温度 であり、 $D^{\prime r}$ は条成分のトレーサ一搪散係数の文献值で ある。

Table 1 の $L_{12}\left(=L_{21}\right)$ の值は決して無視できない くらい大きな值であり，溶鉄中の伝熟と成分の拡散には 比較的大きなカップリング効果があることが判明した。

次に高灼スラグの基本系である $40 \mathrm{wt} \% \mathrm{CaO}-20 \%$ $\mathrm{Al}_{2} \mathrm{O}_{3}-40 \% \mathrm{SiO}_{2}$ の $1500^{\circ} \mathrm{C}$ における等温多元拡散の場

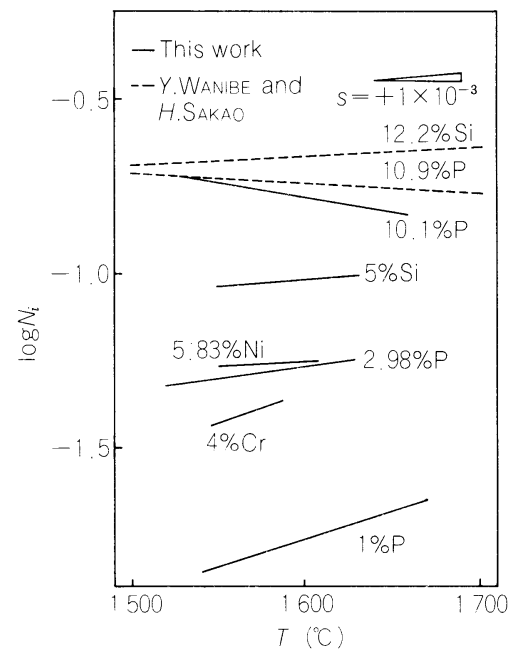

Fig. 4. Steady state distribution of solutes in liquid iron after thermodiffusion.

Table 1. The results of calculation for $s, L_{11}, L_{12}=L_{21}, L_{22}$ and the data of tracer diffusivity used for calculation.

\begin{tabular}{|c|c|c|c|c|c|c|}
\hline Solute & $\begin{array}{l}\text { Temp. } \\
\left({ }^{\circ} \mathrm{C}\right)\end{array}$ & $\left(\begin{array}{c}s \\
\left(\mathrm{~K}^{-1}\right)\end{array}\right.$ & $\begin{array}{c}D^{l r} \\
\left(\mathrm{~cm}^{2} / \mathrm{s}\right)\end{array}$ & $\left(\mathrm{mol}^{2} / L_{11} \mathrm{cal} \cdot \mathrm{cm} \cdot \mathrm{s}\right)$ & $\begin{array}{c}L_{12}=L_{21} \\
(\mathrm{~mol} / \mathrm{cm} \cdot \mathrm{s})\end{array}$ & $\begin{array}{c}L_{22} \\
(\mathrm{cal} / \mathrm{cm} \cdot \mathrm{s})\end{array}$ \\
\hline $10.1 \% \mathrm{P}$ & 1300 & $-7.88 \times 10^{-4}$ & $1.0 \times 10^{-5}$ & $7.3 \times 10^{-11}$ & $2.9 \times 10^{-7}$ & $1.4 \times 10^{2}$ \\
\hline $10.1 \% \mathrm{P}$ & 1597 & $-1.61 \times 10^{-3}$ & $2.5 \times 10^{-5}$ & $1.5 \times 10^{-10}$ & $1.7 \times 10^{-6}$ & $1.77 \times 10^{2}$ \\
\hline $2.98 \% \mathrm{P}$ & 1577 & $+1.43 \times 10^{-3}$ & $2.5 \times 10^{-5}$ & $4.6 \times 10^{-11}$ & $-4.4 \times 10^{-7}$ & $1.77 \times 10^{2}$ \\
\hline $0.99 \% \mathrm{P}^{3}$ & 1610 & $+3.78 \times 10^{-3}$ & $2.07 \times 10^{-5}$ & $1.28 \times 10^{-11}$ & $-3.2 \times 10^{-7}$ & $1.77 \times 10^{2}$ \\
\hline $5.0 \% \mathrm{P}$ & 1590 & $+7.39 \times 10^{-4}$ & $4.19 \times 10^{-5}$ & $1.37 \times 10^{-10}$ & $-6.6 \times 10^{-7}$ & $1.77 \times 10^{2}$ \\
\hline $5.83 \% \mathrm{Ni}$ & 1585 & $+5.72 \times 10^{-4}$ & $5.10 \times 10^{-5}$ & $1.06 \times 10^{-10}$ & $-6.0 \times 10^{-7}$ & $1.77 \times 10^{2}$ \\
\hline $4.0 \% \mathrm{Cr}$ & 1567 & $+4.06 \times 10^{-3}$ & $3.25 \times 10^{-5}$ & $4.85 \times 10^{-11}$ & $-1.3 \times 10^{-7}$ & $1.77 \times 10^{2}$ \\
\hline
\end{tabular}


今の $L_{i k}$ を推定してみよう。成分を示す方法はいろい ろあるが簡便のため元素イオンをとり拡散のフラックス の式を書くと次のようになる。

$$
\begin{aligned}
& j_{\mathrm{Ca}^{2+}}=-L_{11} \nabla \eta_{\mathrm{Ca}^{2+}}-L_{12} \nabla \eta_{\mathrm{Al}^{3+}}-L_{13} \nabla \eta_{\mathrm{Si}^{4+}} \\
& -L_{10} \nabla \eta_{0^{2}} \\
& j_{\mathrm{Si}^{4+}}=-L_{21} \nabla \eta_{\mathrm{Ca}^{2+}}-L_{22} \nabla \eta_{\mathrm{Al}^{3+}}-L_{23} \nabla \eta_{\mathrm{Si}^{4+}} \\
& -L_{20} \nabla \eta_{0^{2}} \\
& j_{\mathrm{Si}^{4+}}=-L_{31} \nabla \eta_{\mathrm{Ca}^{2+}}-L_{32} \nabla \eta_{\mathrm{Al}^{3+}}-L_{33} \nabla \eta_{\mathrm{Si}^{4+}} \\
& -L_{30} \nabla \eta_{0^{2}} \\
& j_{0^{2}}=-L_{01} \nabla \eta_{\mathrm{Ca}^{2+}}-L_{02} \nabla \eta_{\mathrm{A}^{3+}}-L_{03} \nabla \eta_{\mathrm{Si}^{4+}} \\
& -L_{00} \nabla \eta_{0^{2}}
\end{aligned}
$$

ここで $\nabla \eta_{i}$ は $i$ イオン種の電気化学ポテンシャル勾配 であり， $L_{i k}$ の $i k$ の 1,2,3,0 はそれぞれ $\mathrm{Ca}^{2+}, \mathrm{Al}^{3+}$, $\mathrm{Si}^{4+}, \mathrm{O}^{2-}$ に対応する.

(34) ～(37) 式で走義される $L_{i k}$ は 16 個あるがオン セーガーの相父定理により末知数の $L_{i k}$ の数は 10 個に 減る。更に次のような DEGROOT and MAZUR の式 14)によ り末知数は 4 做減り, 6 個のみになる。

$$
\begin{aligned}
& L_{11}+L_{12}+L_{13}+L_{10}=0 \\
& L_{21}+L_{22}+L_{23}+L_{20}=0 \\
& L_{31}+L_{32}+L_{33}+L_{30}=0 \\
& L_{01}+L_{02}+L_{03}+L_{00}=0
\end{aligned}
$$

末知数である $L_{i k}$ は 6 㑉なので, 6 種類の物性值の 信頼できる文献值を用い机ば 16 個すべての $L_{i k}$ は求め られることになる。用いた $1500^{\circ} \mathrm{C} の こ の$ 組成のスラ グの物性值は以下のごとくである。

$$
\begin{aligned}
& D_{\mathrm{Ca}^{2+}}^{t r}=2.1 \times 10^{-6} \mathrm{~cm}^{2} / \mathrm{s}, \\
& D_{\mathrm{A}^{3+}}^{t r}=6.3 \times 10^{-7} \mathrm{~cm}^{2} / \mathrm{s}, \\
& D_{\mathrm{S}^{4+}}^{t r}=2.3 \times 10^{-7} \mathrm{~cm}^{2} / \mathrm{s}, \\
& \sigma=0.127(\Omega \cdot \mathrm{cm})^{-1}, \quad t_{\mathrm{Ca}^{2+}}=0.95, \quad t_{\mathrm{A}^{3+}}=0.05
\end{aligned}
$$

次の Table 2 はこれらの物性値を用いて求めた 16 個 の $L_{i k}$ を $\left(\mathrm{mol}^{2} / \mathrm{cal} \cdot \mathrm{cm} \cdot \mathrm{s}\right)$ の単位で示してある.

この Table 2 に示した $L_{i k}$ は (17) 式で示した条件 を完食に満足している。計算の詳細は文献 15）にある.

さて Table 2 のごとく $L_{i k}$ がもとまつたので (20) 式, (21) 式で走義される相百拡散係数 $\tilde{D}_{i k}$ も求められる. $L_{i k}$ がわかると便利なことがいろいろあるが、 $\tilde{D}_{i k}$ を実 験せずとも得られるのも便利であろう。

$$
\begin{aligned}
& \tilde{D}_{10-10}^{30}=3.2 \times 10^{-6} \mathrm{~cm}^{2} / \mathrm{s}, \\
& \widetilde{D}_{10-20}^{30}=-1.08 \times 10^{-6} \mathrm{~cm}^{2} / \mathrm{s}, \\
& \tilde{D}_{20-10}^{30}=-1.06 \times 10^{-6} \mathrm{~cm}^{2} / \mathrm{s}, \\
& \widetilde{D}_{2020}^{30}=2.04 \times 10^{-6} \mathrm{~cm}^{2} / \mathrm{s}
\end{aligned}
$$

$\tilde{D}_{i k}$ が求められたので, 今仮りに $1500^{\circ} \mathrm{C} て ゙ 40 \mathrm{~min}$

Table 2. Estimated $L_{i k}$ at $1500^{\circ} \mathrm{C}$ for molten $40 \%$ $\mathrm{CaO}-20 \% \mathrm{Al}_{2} \mathrm{O}_{3}-40 \% \mathrm{SiO}_{2}$ system $^{15}$.

\begin{tabular}{l|l}
\hline$L_{11}=1.1 \times 10^{-11}$ & $L_{13}=-2.0 \times 10^{-12}$ \\
$L_{22}=1.8 \times 10^{-12}$ & $L_{23}=-5.5 \times 10^{-13}$ \\
$L_{33}=1.1 \times 10^{-12}$ & $L_{10}=-7.1 \times 10^{-12}$ \\
$L_{00}=5.1 \times 10^{-12}$ & $L_{20}=6.1 \times 10^{-13}$ \\
$L_{12}=1.9 \times 10^{-12}$ & $L_{30}=1.5 \times 10^{-12}$ \\
\hline
\end{tabular}

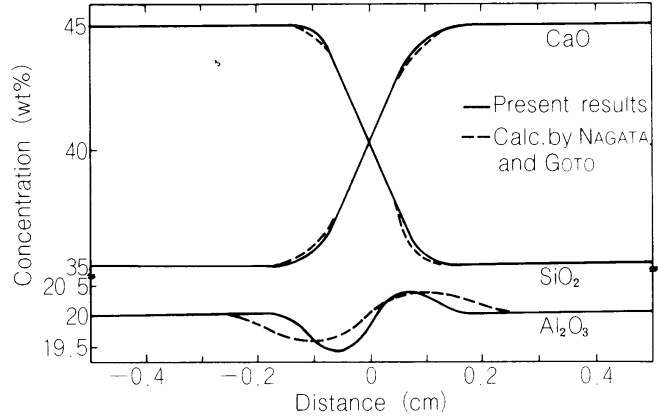

Fig. 5. Concentration distribution of $\mathrm{CaO}, \mathrm{SiO}_{2}$ and $\mathrm{Al}_{2} \mathrm{O}_{3}$ after diffusion of $40 \mathrm{~min}$ at $1500^{\circ} \mathrm{C}$. The broken lines are estimated from the transport coefficients and the solid lines are experimental results.

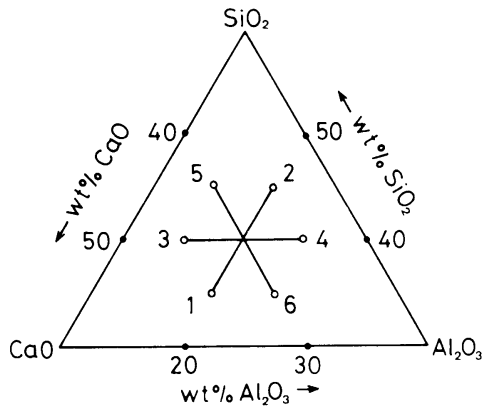

Fig. 6. A diagram to show compositions of six kinds of the slag samples of lime-silica-alumina ternary system used for the diffusion couple experiment.

だけ拡散対で相互拡散実験を行つた後の $\mathrm{CaO}, \mathrm{SiO}_{2}$, $\mathrm{Al}_{2} \mathrm{O}_{3}$ の濃度分布を推分してみよう。Fig. 5 の战線が 推定結果である。この汹は $\mathrm{CaO}$ と $\mathrm{SiO}_{2}$ の相台搪散に カップリングして濃度が均一な $\mathrm{Al}_{2} \mathrm{O}_{3}$ が Up-Hill 拡散 していることを意味している。この焦線の推定結果を実 験で実際に証明した結果が実線のカーブである。比較的 良く一致しているので Table 2 に示した $L_{i k}$ の值は妥 当な值であることがわかつた。

相互拡散対による実験の詳細は文献 16) にあるが, その概略を記すると Fig. 6 に亦すように汹中の 1, 2, 3, $4,5,6$ の 6 種の組成の液体を高温から急冷し棒状のガ ラス状のサンプルをつくる. 次に 1 と 2,3 と 4,5 と 6 のごとき三つの種類の拡散対を作り，比重の重いおを下 方に細いアルミナ管にピッチリはめ迄んで所走の拡散温 度に加熱保持する。

Fig. 7 は $1500^{\circ} \mathrm{C}$ で $20 \mathrm{~min}, 40 \mathrm{~min}, 80 \mathrm{~min}$ 保持し た後の各成分の $\mathrm{wt} \%$ と $x / \sqrt{t}$ の関係汹である. 搪散 時間は 3 種類なのに $x / \sqrt{t}$ に対してプロットすると理 論どおり同一の曲線の上にのるので実験は成功している と考えられる。 


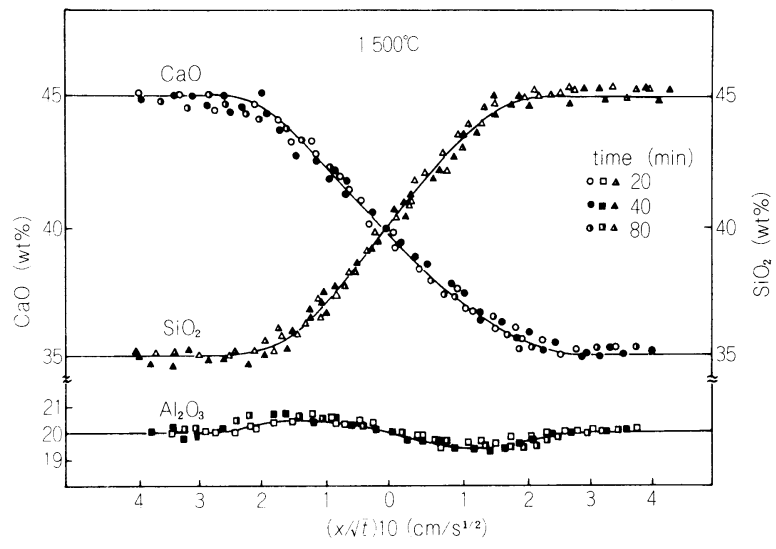

Fig. 7. Relation between weight percentages of the components and distance divided by square root time after diffusion for 20,40 and $80 \mathrm{~min}$ at $1500^{\circ} \mathrm{C}$.

52 本の搪散刘で $1450,1500,1550^{\circ} \mathrm{C}$ のつの温度 で抬散志騃を行い次のように $\tilde{D}_{i k}$ を温度の関数として 得ている16!.

$$
\begin{aligned}
& \widetilde{D}_{10 \quad 10}^{30}=8.9 \times 10^{-11} \exp \left(-\frac{254000}{R T}\right)\left(\mathrm{m}^{2} / \mathrm{s}\right) \\
& \tilde{D}_{1020}^{30}=-2.5 \times 10^{-11} \exp \left(-\frac{194000}{R T}\right)\left(\mathrm{m}^{2} / \mathrm{s}\right) \\
& \tilde{D}_{20}^{30}{ }_{10}=-4.0 \times 10^{-11} \exp \left(\begin{array}{c}
178000 \\
R T
\end{array}\right)\left(\mathrm{m}^{2} / \mathrm{s}\right)
\end{aligned}
$$

$$
\tilde{D}_{20}^{30}=6.12 \times 10^{-11} \exp \left(-\begin{array}{c}
318000 \\
R T
\end{array}\right)\left(\mathrm{m}^{2} / \mathrm{s}\right)
$$

ド於の凹つの式中の活性化エネルギーは $\mathrm{J} / \mathrm{mol}$ で与. えてある。

现在，溶鉄・溶融スラグ巾の成分のトランスポート係 数の呓筑は以上のように2 元系溶融鉄合金と $40 \mathrm{wt} \%$ $\mathrm{CaO}-20 \% \mathrm{Al}_{2} \mathrm{O}_{3}-40 \% \mathrm{SiO}_{2}$ のつつの場合についてのみ 叮能である。しかし，次節で示すような諸物性值の測定 が畜皘されれば将米は 3 元系鉄令金，多成分系製銑スラ グあるいは製鎆スラグ，多元系耐火物中ならびにその粒 界搪散などについてもいろいろな場令についてのトラン スポート係数が求められるようになるであろう。

\section{5. トランスポート係数を計算するための諸物性 値の測定}

種々の組成範䍏の溶鉄, 溶融スラグのトラィスポート 係数を去い温度範同で部算するには諸物性值の測定がま だまだ不足している。これを補うために筆者らはいくつ かの物性储の測定を行つてきた。以下にその測定法と測 分結果を簡略に紹介寸る。Fig. 8 は文献 13）に詳細が

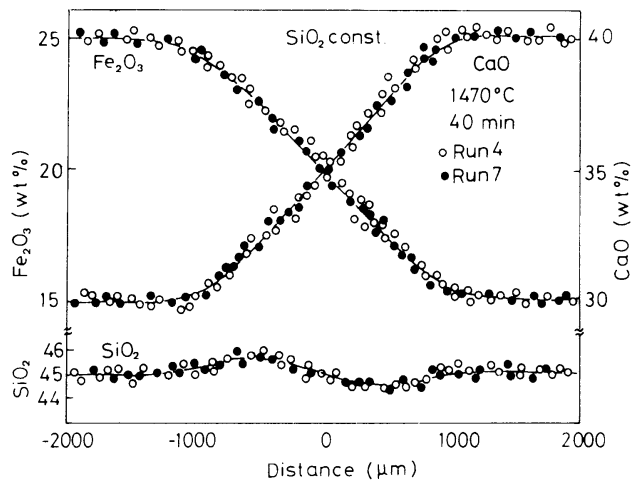

Fig. 8. Distribution of $\mathrm{Fe}_{2} \mathrm{O}_{3}, \mathrm{SiO}_{2}$ and $\mathrm{CaO}$ after diffusion of $40 \mathrm{~min}$ at $1470^{\circ} \mathrm{C}$.

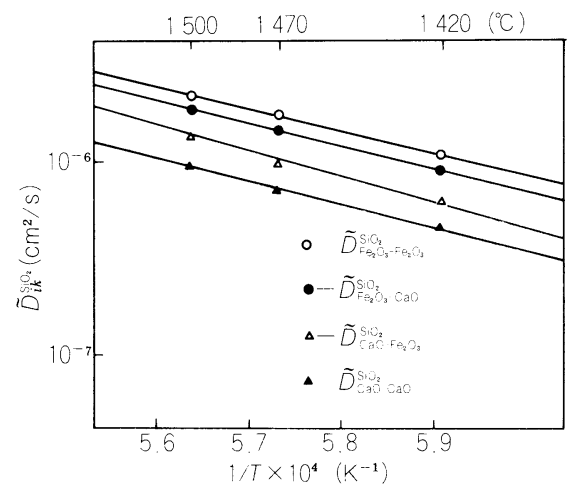

Fig. 9. Relation between logarithm interdiffusivities and reciprocal absolute temperature for ternary system of $\mathrm{Fe}_{2} \mathrm{O}_{3}, \mathrm{CaO}$ and $\mathrm{SiO}_{2}$.

あるが, 液体 $\mathrm{CaO}-\mathrm{Fe}_{2} \mathrm{O}_{3}-\mathrm{SiO}_{2} 3$ 元系スラグの $1470^{\circ} \mathrm{C}$, $40 \min$ の拡散実験後の濃度分布であり $\mathrm{SiO}_{2} に \mathrm{Up}$-Hill diffusion がみとめられる. 
Fig. 9 はこの 3 元系液体の相互拡散係数マトリック スのアーレニュースプロットであり, クロス項は 2 個共 にマイナスの值をとつている. $\tilde{D}_{i k}$ の絶対值は約 $10^{-6}$ $\mathrm{cm}^{2} / \mathrm{s}$ くらいである. 文献 13）の Fig. 12，13，14に

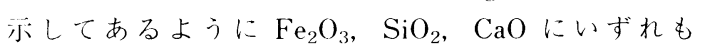
Up-Hill diffusion がみとめられたので, $\mathrm{Fe}^{3+}, \mathrm{Ca}^{2+}$, $\mathrm{Si}^{4}$ の拡散ジャンプには無視できない程度のカップリ ング垷象があることが判明した。

Fig. 10 はスラグ中の熱拡散の・例である。涳媒とし て用いたスラグは $40 \mathrm{wt} \% \mathrm{CaO}-40 \% \mathrm{SiO}_{2}-20 \% \mathrm{Al}_{2} \mathrm{O}_{3}$ で

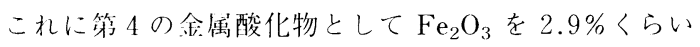
添加した。

実験にはFig. 2 に示したようなたて型の細长いアル ミナ管を用いた。

Fig. 11 は闬じく $40 \mathrm{CaO}-40 \mathrm{SiO}_{2}-20 \mathrm{Al}_{2} \mathrm{O}_{3}$ に $\mathrm{P}_{2} \mathrm{O}_{5}$, $\mathrm{MgO}, \mathrm{TiO}_{2}, \mathrm{Fe}_{2} \mathrm{O}_{3}$, あるいは $\mathrm{MnO}$ を添加した場命の

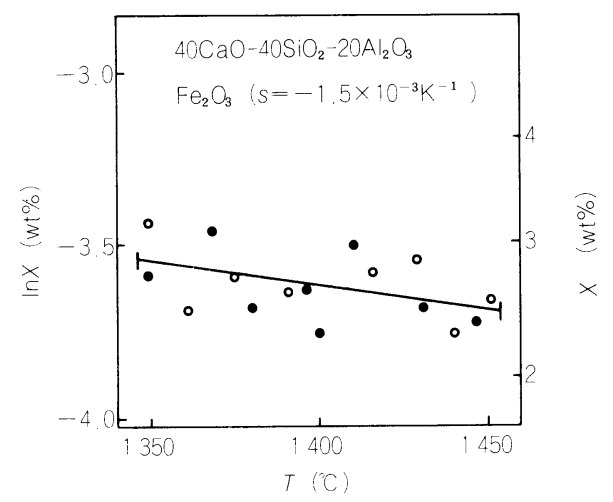

Fig. 10. Distribution of $\mathrm{Fe}_{2} \mathrm{O}_{3}$ in $40 \% \mathrm{CaO}-40 \% \mathrm{SiO}_{2}-$ $20 \% \mathrm{Al}_{2} \mathrm{O}_{3}$ after thermodiffusion.

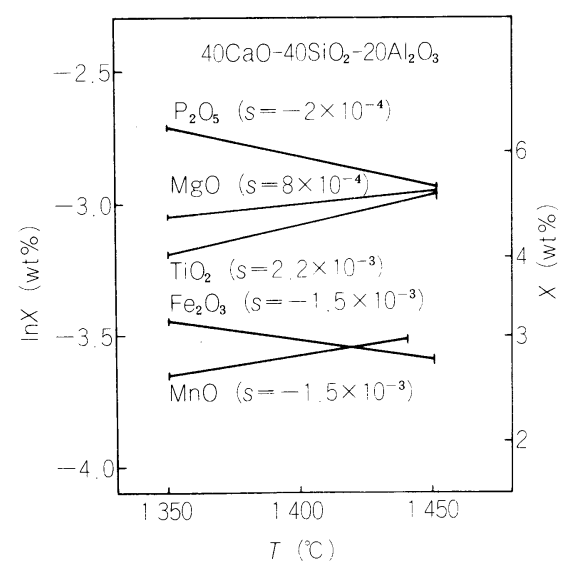

Fig. 11. Distribution of various solute oxides dissolved in a solvent of $40 \% \mathrm{CaO}-40 \% \mathrm{SiO}_{2}-20 \% \mathrm{Al}_{2} \mathrm{O}_{3}$ after the thermodiffusion.
熱拡散実験の結果を示している。溶媒として用いた $\mathrm{CaO}-\mathrm{SiO}_{2}{ }^{-} \mathrm{Al}_{2} \mathrm{O}_{3}$ の各成分も熱拡散現象を多少おこし ているにちがいないが，X線マイクロアナライザーの分 析精度では均一に観察された。刚中に書き込んであるり レー係数は溶媒と溶質の擬 2 元系として計算した結果で ある。

Fig. 12 は $25 \mathrm{wt} \% \mathrm{Fe}_{2} \mathrm{O}_{3}-30 \mathrm{wt} \% \mathrm{CaO}-45 \mathrm{wt} \% \mathrm{SiO}_{2}$ を溶媒とした場仓の $\mathrm{TiO}_{2}, \mathrm{NiO}, \mathrm{P}_{2} \mathrm{O}_{5}, \mathrm{MnO}, \mathrm{MgO}$ の熱拡散実験後の定常濃度分析を少している。文献 13) の Table 2 にソレー係数が触苂してあるが, 本稿の $s$ の定義を用いるとその符罗が逆になつている.

さて次に液体スラグの熱起電力の測定について記す る。熱起電力は (29) 式の所で就したように㨁接 $L_{i k}$ とは関係しないがトランスファー熱 $Q_{i}$ を通して関係づ けることができる6). したがつて将米 $L_{i k}$ をいろいろな

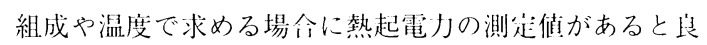
い.

Fig. 13 は液体スラグを練衰いボートに人れ，た布の 温度に差をつける力法を示している。液体スラグは温度 差によつて対流するのでこれを防㤝するために中䦌に”。 つのせきをつくる，左不に $\mathrm{Pt}-13 \% \mathrm{Rh} \cdot \mathrm{Pt}$ 熱電対のホッ

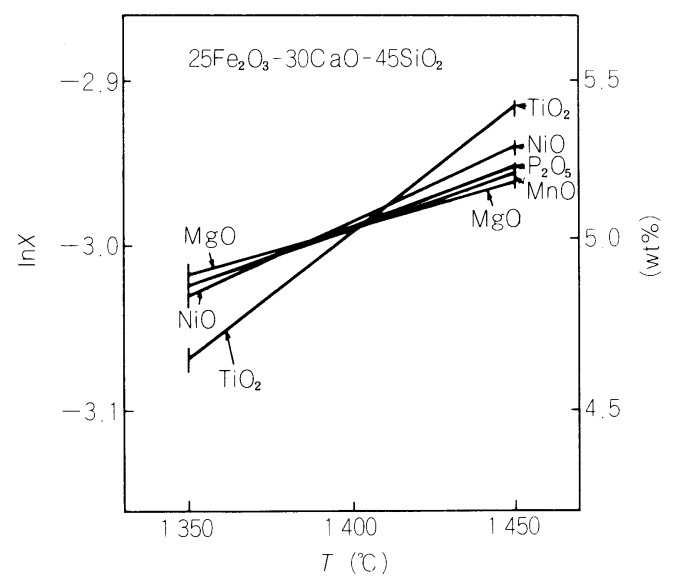

Fig. 12. Distribution of various solute oxides in the solvent of $25 \% \mathrm{Fe}_{2} \mathrm{O}_{3}-30 \% \mathrm{CaO}-45 \% \mathrm{SiO}_{2}$ after thermodiffusion.

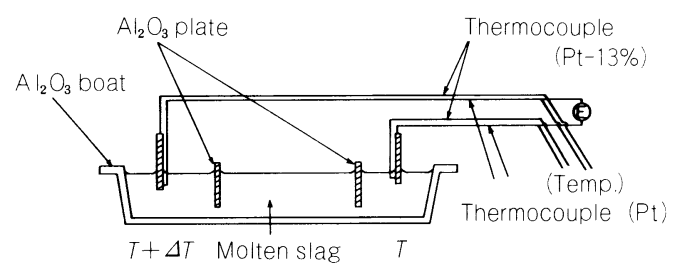

Fig. 13. A schematic diagram of a horizontally long crucible containing liquid oxide with temperature gradient to measure thermo-electromotive force. 


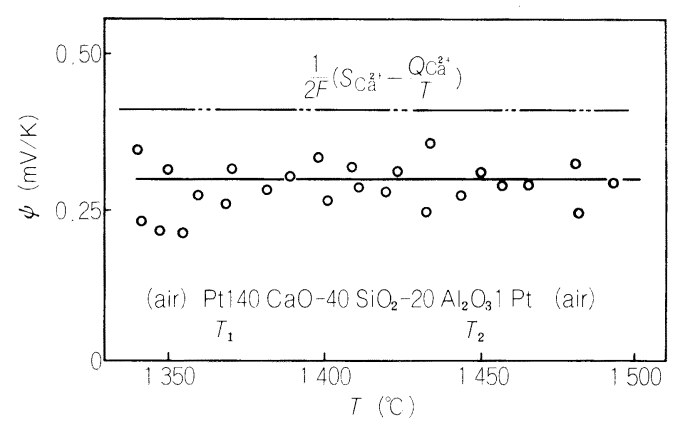

Fig. 14. Relation between thermo-electromotive force per degree and mean temperature for liquid $\mathrm{CaO}-\mathrm{SiO}_{2}-\mathrm{Al}_{2} \mathrm{O}_{3}$. The open plots are measured data the chain line is the absolute thermo-electromotive force of the fused oxide per degree.

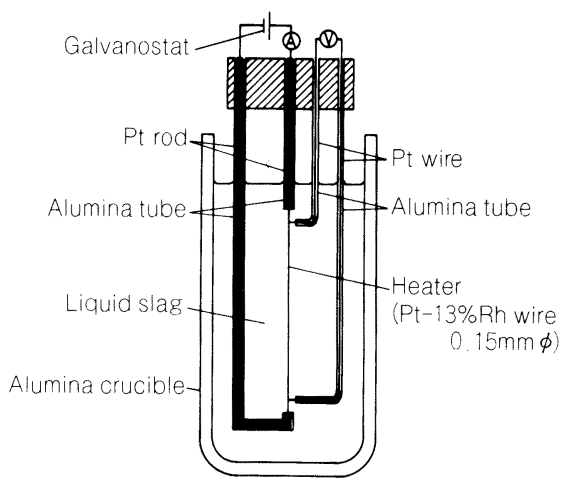

Fig. 15. A schematic diagram of the hot wire method to measure the heat conductivity of liquid oxides. The temperature change of the platinum hot wire is estimated from the potential drop between two electrodes attached to the hot wire.

トジャンクションを浸淇して, 画艮の温度と间時に $\mathrm{Pt}$

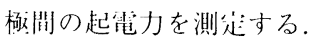

Fig. 14 は縦軸が温度等1度あたりの起電力を $\mathrm{mV}$ で 示し横軸は平均温度を示している。液体スラグ組成は 40 wt \% CaO-20 wt \% $\mathrm{Al}_{2} \mathrm{O}_{3}-40$ wt $\% \mathrm{SiO}_{2}$ で胀中に示し

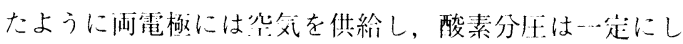
てある。

㕳中白プロットは先測值であり, 温度の高い方の極が プラス極であつた。この实測优より（29）式の不辺第 3 項すなわち $\mathrm{CaO}-\mathrm{Al}_{2} \mathrm{O}_{3}-\mathrm{SiO}_{2}$ 液体スラグの絶対熱電能 を計算し、刚中 2 点鎮線で示した。 (29) 式の布辺第 1 項と第 2 項は熱力学的データより計算し, 第 4 項は文献 值 $0.025 \mu \mathrm{V} / \mathrm{K}$ を用いた。計算の解細は文献 17)にある。 なお文献 17) には䦌体酸化物 $\mathrm{ZrO}_{2}-11 \mathrm{CaO}$, $\mathrm{ZrO}_{2}-9 \mathrm{MgO}, \mathrm{ZrO}_{2}-8 \mathrm{Y}_{2} \mathrm{O}_{3}$ 拈よび液体 $\mathrm{PbO}, \mathrm{PbO}-$ $10 \mathrm{wt} \% \mathrm{SiO}_{2}, \quad \mathrm{PbO}-25 \mathrm{wt} \% \mathrm{SiO}_{2}$ などについての絶対起

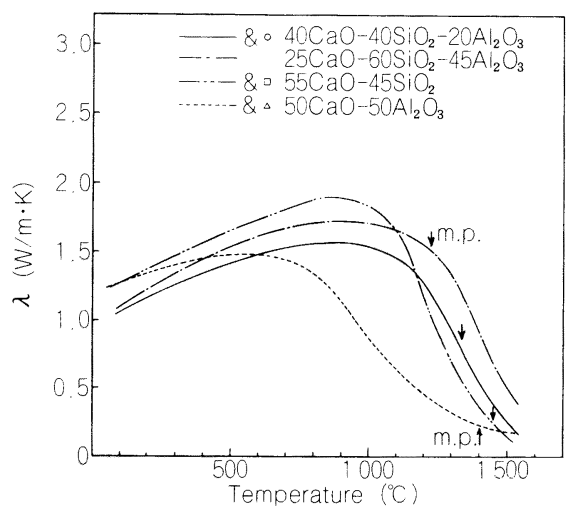

Fig. 16. Relation between heat conductivity and temperature for $\mathrm{CaO}$-based slags with different compositions.

電能を報年してある。

さて（1）（4）式にもどつてみると， $L_{44}$ を求める

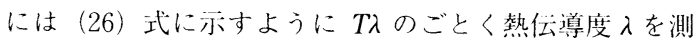
定して抢けば簡単に $L_{44}$ は求められる。液体鉄の熱伝 導度は文献值もあるが液体スラグについては信頼できる ような測定值が無い。そこで筆者らはFig. 15 に示すよ うな熱線法で液体スラグの熱伝導度を測定した。测走原 理は以下のと扔りである。縦長の深いるつぼの中に液体 スラグを溶解し一定温度に保持する。次にぴんと張つた 細い白全線を垂直に静かに浸漬する。この垂㨁な白金細 線に一分電流密度で外部より電流を供給する。するとこ の白金線はジュール熱によつて温度が上昇する。どのく らい温度が上昇したかは白金線の上下に溶接した 2 極間 の電压降下より白金線の抵抗変化を知り，既知の白金の 比抵抗の温度の関数式より温度上昇の程度を求める. 白 金線のまわりの液体スラグの熱伝導度が小さければ，白 金線の温度上昇は速く，逆にスラグの熱伝導度が小さけ れば，温度上昇は遅い。

白金線の温度上昇速度を電流密度とスラグの熱伝導度 の関数として示すにはフーリエの伝熱の第 2 法則を解く と得られる。 Fig. 16 は測定結果の一例として $\mathrm{CaO}$ 基 のスラグの熱伝導度 $\lambda(\mathrm{W} / \mathrm{m} \cdot \mathrm{K})$ と温度の関係を示し ている.

网中スラグ成分の前に付した数字:は wt \% を意味して いる。これらのスラグは融点以下でもアモルファス状態 になつているので, 融点において階段的に熱伝導度は変 化していない。詳細は文献 18）にあるが，この文献に はいろいろなスラグ組成のものについての広汎なデータ がある。また文献。19）には高炉現場スラグや連続鋳造 用フラックスの熱伝導度のデー夕もある。また文献 20) には製銑，製鋼用各種耐火物の熱伝導度もある.

以上が $(1) \sim(4)$ 式で定義した $L_{i k}$ を求めるに必 要な諸物性值の測定方法と測定結果のいくつかの例であ 
る.

\section{6. 溶鉄, 溶涬成分のトランスポート係数の意義 と将来の課題}

浴鉄，溶滓の成分のトランスポート係数を知る目的に は兴術的目的とに業的目的がある。学術的目的は緒百に

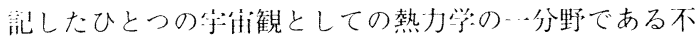
仃逆過程の熱力学を深く理解するためである。熱力学をを 深く理解す机ばその哲学的な一面も理解でき, 結果とし て今後投稿するであろう研究論文のひとつひとつに哲学 的見地を加味することができよう。また兴閭上の具体的 目的は高温の無機化命物の関与する自然現象の中にどん なカップリング現集がどの程度牛起しているかを明らか にすることにある。本稿に亦すようにこの学閣的目的は ほんの少ししか達成されていない。トランスポート係数 $L_{i k}$ が種々の場令について求められれば，(16) 式にし たがつてエントロピー生成速度が空量的に求められる。 すなわち熱力学:の第 2 法則のエントロピー増大の法則の 全性的理解がより具体的，より定量的理解に変えること ができる。このような知的好命心を満足させることも目 的のひとつである。

门業的目的は「高灯，いろいろな吹迟精鍊，上底吹転 吙， RH，DH，そして連続鋳造の諸」程でカップリング 现集はどの程度抢きていて，广程管理上これを無視して 艮いのであ万うか？」という問いに答えることである。

本稿に示した測起例は非常に限られているが，その多元 搪散に抢けるUp-Hill diffusion や熱㕬散の程度をみる とこれらのカップリング现象はけ程管理上無視して良い くらい小さいようにみえる。したがつてトランスポート 係数を求めることは1業的に一見無意味に見えるが，む しろそのI業的価值は溶銑, 浴㵏の種々の組成域におけ る必要な物性值の推定にある。相而搪散係数は製鍊父忍 速度の推定に必要でもほとんど实測值が無い。 $L_{i k}$ が他 の物性值よりわかつてい机ば簡単に说明される。また， $L_{i k}$ 在求めるためいろい万な测等を試みる。 その結果, 例えば連続鋳造フラックスの熱伝導度のようには業的に 重要な物性值も測走叮能になる。すなわちトランスポー 卜係数を求めようとすることは必然的に1程管理卜必要 な諸物性值のデー夕を明らかにしてゆく。これがトラン スポート係数を求めることの1業への糞献である。こう してみると将来の課題は明らかで, 学術的課題としては (1)～(4) 式で定義されるトランスポート係数をもつ といろいろな種類の液体酸化物や液体今金系で坛い範䎴 について求めてゆくことである.

そうすると $L_{i k}$ の組成依存性と温度依存性について ある種の経験則を発見できるかもしれない。また $L_{i k}$ とフラックスの式よりエントロピー生成速度を求めると 興味ある事実をみつけることができるかもしれない．

1. 業的課題は一見無視できるかに見えるカップリング

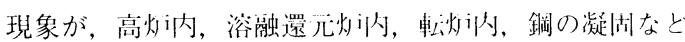
に扮いて本当に無視して垦いか不加を州らかにする研究 を行うことである。

また，上記のようにトランスポート倸数はに業的に必 要な諸物性值の測走に必接に㴨倸しているので, 将来け 業的に必要な諸物性值をよく分類して测定することも車 要な課題である。この場今トランスポート係数の形で デー夕を整理しておくと他の物性:佃への変換に便利であ る.

本稿に扔いては溶鉄，淮㳯について述心゙たが，将来の 課題としては大きな温度么酒下にある灼酎火物の中の 粒界拡散や，高灯溶融带などに扔ける煳液基份域に扮け る搪散など，阔体の関係した高温垷䇣に扮けるカップリ ング現象の研究も重要な課題のように艺えられる。

また鉄鋼製鍊の基礎研究を行つている若い人々は熱力 学の勉強を当然していると思うが，緒命に綃介した松下 幸雄先牛の3 回の溝義や文献 4) や14) 在泊して不川 逆過程の熱力学ををも勉強するとより㤟かな鉄汸金学考築 くことができるにちがいない.

なお本稿では議論を簢明にするために，筆考らのこの 方面の研究のみ引用したが，1879 作のS SORETの熟搪散

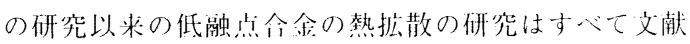
11にに引用紹介してある。また㵋融硝酸塩のトランス ポート係数の河村和考などによる研究は文献 5)に少用 してある。またいろいろな物質の熱起電少, 例えば溶融 $\mathrm{FeO}$ の熱起電力に関する汇自，下地の研究は文献 11) に緭介してある。あわせて御参照いただければ故いであ る。

本稿で引用した文献 5）6）10）11）13）15－20）の 研究を行つてくれた下就のノ々に深い感謝老表します。

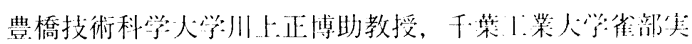

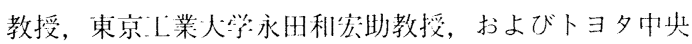

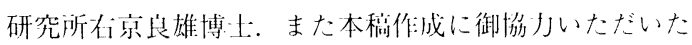
東京卜業大学須佐居裕助手に感谢する。

\section{文献}

1）松下幸雄: 鉄と鋼，43 (1957)，p. 749

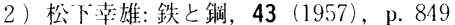

3 ) 松下幸雄: 鉄と鋼, 43 (1957), p. 1153

4) I. Prigoginf: Introduction to Thermodynamics of Irreversible Processes. New York (1955) [Interscience Publishers of John Wiley \& Sons]

5 ) 後藤和弘, H. S(HMAI.ZRIEI, 永H利公: 鉄と鍓, 61 (1975), p. 2794

6) K.S. Goto, K. Natiata and Y. UKYo: Canadian Metallugical Quatery, 20 (1981), p. 117

7) H. Fumta and L. J. Gosting: J. Am. Chem. Soc., 78 (1956), p. 1099

8) J. S. Kirkat.oy: J. Phys., 35 (1957), p. 435

9) R.W. Larry: The Structure and Properties of Ionic Melts (1962) [The Aberdeen Univ. Press, Limitted]

10) K. S. GoTo, M. Sasabe and M. KaWAKami: Trans. ISIJ, 17 (1977), p. 212

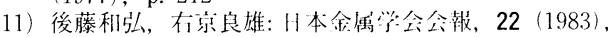
p. 205 
12) $Y$. Wantri: and $H$. Sikan: Arch. Eisenhüttenwes., 44 (1973), p. 573

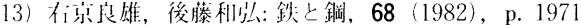

14) S. R. DeGroor and P. Mazr: Non-equilibrium Thermodynamics (1969), p. 278 [North-Holland Pub. Co.]

15) K. Nagata and K. S. GoTo: J. Electrochem. Soc., 123 (1976), p. 1814

16) H. Siqiawaka, K. Nagiati and K. S. Goto: Metall. Trans., 8B (1977), p. 605

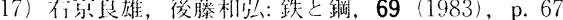

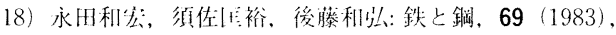
p. 1417

19) $K . S$. Goto, $H . W$. Gunende, $K$. Nagiatd and $K . H$. L.indoner: Stahl Eisen, 105 (1985), p. 1387

20）永田和厷，铰谷川泰十，後藤利少：鉄と鋼，70（1984）。 p. 374 